\title{
Competitiveness in Insular Regions: Case of Isla Grande in the Archapelago of Islas Del Rosario, Cartagena, Colombia
}

\author{
JORGE DEL RIO-CORTINA \\ Business School \\ Universidad Tecnológica de Bolívar, COLOMBIA \\ MIKEL IBARRA-FERNÁNDEZ \\ Business School \\ Universidad de la Sabana, COLOMBIA \\ CARLOS RODRÍGUEZ-ARIAS \\ Faculty of Administration \\ Escuela de Formación de Infanteria de Marina, COLOMBIA \\ NAOMI LÓPEZ-ESPITIA \\ Faculty of Administration, Universidad del Sinu, COLOMBIA
}

\begin{abstract}
This article is based on a study whose objective was focused on identifying the variables and key actors with the greatest impact on the competitiveness of a large island in the island region of the Rosario Islands in Cartagena, Colombia. The implemented methodology is exploratory, based on the qualitative paradigm, and had three phases. The first was developed through a competency diagnosis that was achieved from observations and discussions with the community. The second phase was the identification of the actors to determine how they affect the community. The final phase included the identification of probabilistic cross impacts. The main findings of the research include that the main external factor is the sociodemographic variable. In addition, the environmental variable directly influences competitiveness. The following internal variables of the large island community were identified: ecotourism, poverty and misery index, exploitation of natural resources, social innovation, tourism potential and generational change. Finally, it is necessary to perform immediate actions in favour of the development of competencies. Some of these actions include promoting the destination as ecotourism and developing campaigns to raise awareness of the importance of the island for natural resources and that these resources should be conserved.
\end{abstract}

Keywords: Regional forecasting, Regional competitiveness, Island Community, Island regions

Received: October 12, 2019. Revised: April 28, 2020. Accepted: May 7, 2020. Published: May 11, 2020.

\section{Introduction}

As a result of economic globalization, competitiveness has increased disproportionately, thus influencing how companies project into markets. Given this reality, it is necessary for companies to strengthen their competitive advantages and achieve sustainability to adapt and survive in a complex market [24]. According to Avendaño Avendaño, Mondragon, \& Fuertes Diaz [3], forecasting as a discipline for building the future focuses on what is to be achieved and what must serve all actors to act with greater security in the present. Therefore, if regions implement this purpose, they will be more competitive because 
they will be able to anticipate the events of the present in time to gain the upper hand against regional stagnation and underdevelopment.

Competitiveness is a relatively broad concept of the ability to generate value and socioeconomic well-being for the inhabitants of a region. It is possible to approximate the competitiveness that permits a global view of those countries that have low competitiveness indices.

The World Economic Forum, through the Global Competitiveness Index (GCI), measures the ability of a nation to achieve sustained economic growth over the medium term. This is accomplished by means of three factors: i) basic conditions, ii) efficiency, and iii) sophistication and innovation. According to the results for 2016 of the GCI worldwide, Switzerland continues to be the most competitive country, followed by Singapore and the United States. India showed the greatest progress, rising 16 places in the general ranking for the reference year.

Regarding Latin America and the Caribbean, Colombia (position 61) remains the fifth most competitive country in the region, after Chile (33), Panama (42), Mexico (51), and Costa Rica (54). In Latin America and the Caribbean, the countries with the lowest rankings were Bolivia (121) and Venezuela (130) [42]. In Colombia, competitiveness is measured through the Departmental Competitiveness Index (DCI), which evaluates regional competitiveness based on three factors: i) basic conditions, ii) efficiency, and iii) sophistication and innovation, similar to the GCI.

In 2015, Bogotá D.C. (score 8.13) ranked first in the overall DCI rankings, while the Bolívar department (4.40) ranked 12th. By factors, Bogotá D.C. ranks as follows: basic conditions (position 1, score 6.99), efficiency (position 1, score 8.21), sophistication and innovation (position 1, score 9.61); the Bolívar department ranks as follows: basic conditions [position 16; score 5.03], efficiency (position 12; score 4.01), and sophistication and innovation (position 9; score 4.41) [11]
Given these conditions, Isla Grande is a territory that belongs to the archipelago of Rosario in the jurisdiction of Cartagena de Indias, located in the Caribbean Sea at north of Colombia, is an island with great tourist attraction, with heavenly beaches and an excellent cultural and gastronomic variety, however in the island region of Isla Grande, the object of this study of trying to achieve sustained competitiveness becomes a challenge primarily due to the poor living conditions of its inhabitants, observable through unsatisfied basic needs and environmental risk, products of unaware human activity.

Under this framework, there is a need to integrate the concept of competitiveness and tourism because, from tourism, it is possible to achieve a form of competitiveness that integrates the internal and external strengths of the island and that allows for the socioeconomic well-being of its population. Considering that tourism has been growing considerably over the years, tourism is seen as a catalyst for the socioeconomic development of regions and countries. Moreover, the World Tourism Organization has prioritized the year 2017 as the International Year of Sustainable Tourism for Development for social inclusion, environmental conservation and the cultural heritage of tourist destinations [43]

In summary, the problem of Isla Grande lies in the need to be a region that is competitive with other island destinations, seeking the most efficient and least damaging means for its sustainability, which ultimately results in a better quality of life for its population as the ultimate goal of the competitive process, projecting this vision of regional sustainability into the future.

\section{Theoretical Background}

\subsection{Competitiveness as a Result of Regions}

Competitiveness is a multidimensional concept that can be defined from three different levels: countries, industry and companies. Competitiveness has also been used to describe the "economic capacity of an entity with respect to its competitors in global markets in which 
goods, services, people, skills and ideas move freely across geographical boundaries" [37], to mention representative authors from the perspective of national competitiveness.

Porter [37], establishes that "the only basis for national competitiveness lies in productivity." $\mathrm{He}$ proposes that productivity is the principal determinant in the long career of a nation for the development of quality of life for its inhabitants. For him, productivity is determined by trade in goods and services that determine national competitiveness. However, Porter changes his stance on the relationship between competitiveness and productivity arguing that "national competitiveness is determined by comparative productivity; then later it is established that Porter confuses comparative advantage with absolute advantage" [7][34] [31]. However, in the view of business competitiveness, Krugman [27], criticizing the postulates of Porter, "maintains that competitiveness is not a concept applicable to nations since, in fact, internal growth rates and the level of productivity of the companies are what determine the level of competitiveness of populations."

Some authors of competitiveness relate company perspective to the competence approach. They emphasize the role of the "internal factors of the companies such as strategy, structure, competencies and capacity for innovation in addition to other tangible and intangible resources for competitive success" [1][34]. This view of competitiveness is closely related to resource dependency theory, among which authors such as Peteraf, [36] Barney, Wright, \& Ketchen [5], Grant, [21] Prahalad \& Hamel, [38] are found.

Similarly, Bolfa [6] states that it is necessary to address issues such as the current economic and environmental context to develop regional development studies. As well as Nurhayati, Aisyah, \& Supriatna [35] who affirm that it is necessary to take into account the relevance of the socio-economic dimensions to potentiate marine resources such as coral fish, coral reefs, sea grasses, algae, sea turtles, mangroves and white sand beaches and that at the same time it should not conflict with fishing activities, in that sense, development should be accompanied by both activities as a complement.

Given this, it is important to conduct a review of the term "competitiveness" based on representative authors from its three levels: nation, industry and company. This conceptual review provides approximations towards a consensus on competitiveness that could be summarized in the ability of countries to generate well-being for the populations by increasing their quality of life. However, the specifications to the scope of the concept have gone beyond the three levels mentioned above. In this sense, regional and destination competitiveness has gained relevance, from which theories have been proposed on how to improve their competitiveness. A Kozak \& Rimmington [26] mention "the importance of the competitiveness of tourist destinations in tourism systems, as this becomes the central tool that allows tourism development."

For his part, D' Hauteserre, [12] alludes that "the competitiveness of destinations is their ability to maintain a position in the market and improve that position over time." Additionally, Heath, [23] suggests destination competitiveness as the "capacity in the availability of products and services that are better compared to other tourist destinations based on the tourist experience, i.e., the perception of the tourist." Ritchie \& Crouch, [40] are the references in terms of the competitiveness of tourist destinations; they refer to the fact that competitiveness "is the ability to add value by increasing the wealth of the destination" considering an economic and social model in which the resources available to the destination and its preservation are the objective of this. For the explanation of destination competitiveness, Crouch and Ritchie propose a conceptual model titled the Calgary Model in which they establish that considering a tourist destination as competitive is to consider that the destination will contribute to the well-being of the population [8]. This model is configured from two elements that are crucial for destination 
competitiveness. The first is the comparative advantage of the destination, that is, the endogenous or internal resources of the destination.

The second element is competitive advantage, which refers to deployed resources that are capable of effective use in the long term. Competitiveness for Crouch and Ritchie depends on resources and basic attractors and supporting factors and resources, taking into account the direction of the destination as a key element that maintains the sustainable competitive advantage
[8]. An adaptation to the Crouch and Ritchie model is the model proposed by Dwyer \& Kim, [14], which is called the Integrated Destination Competitiveness Model. These authors propose a system of indices for each determinant of tourism competitiveness that are integrated to configure those factors that influence the performance of tourist destinations [15]. The system contains many of the variables that Crouch and Ritchie have identified in their model and recognizes that demand conditions play an important role in determining destination competitiveness Dwyer \& Kim, [14].

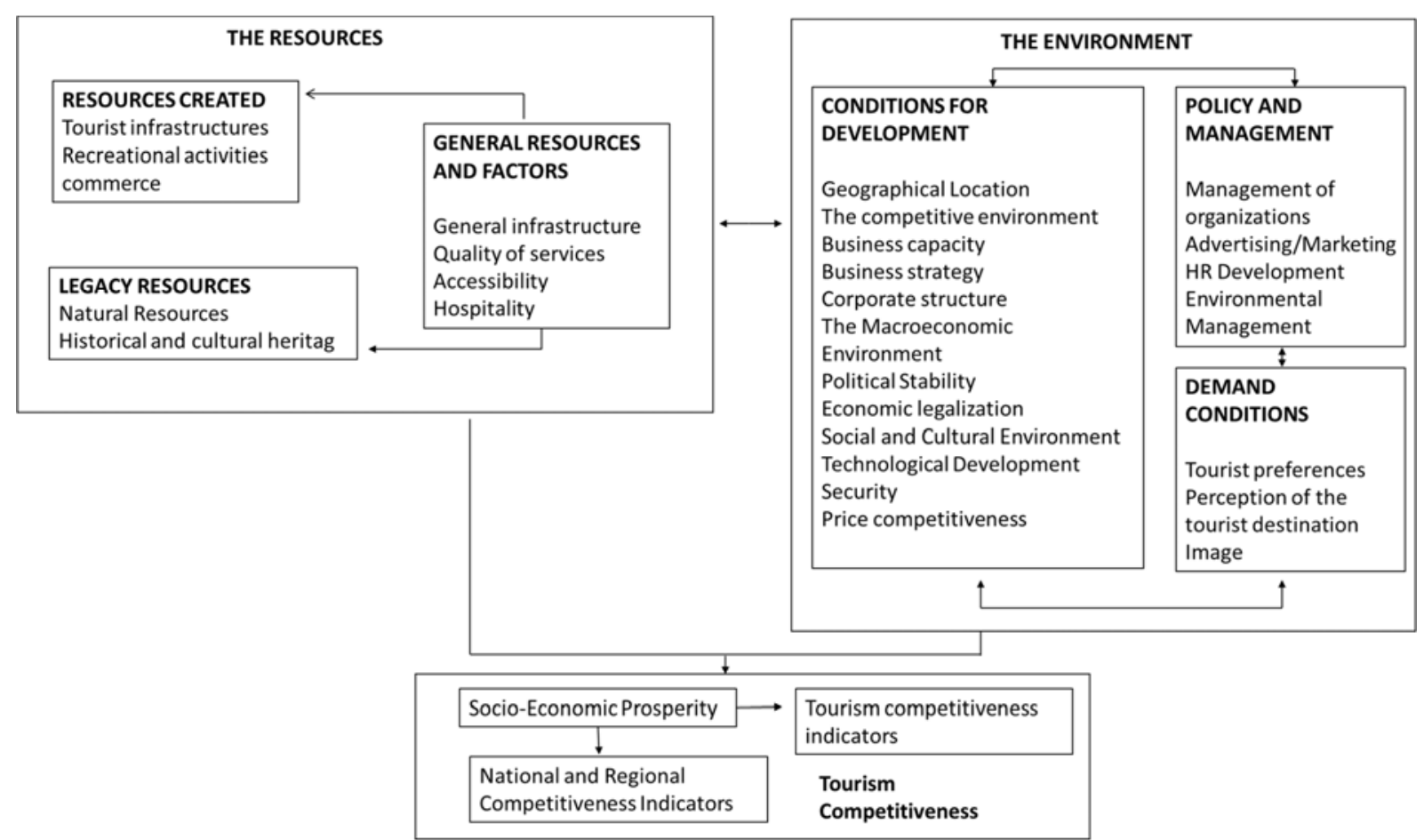

Fig. 1. Integrated Model of Destination Competitiveness, Dwyer and Kim Source: Dwyer and Kim [2003] cited in Diéguez Castrillón et al. [2011]

\subsection{From the Integrated Model of Destination Competitiveness to Regional Competitiveness}

According to the previously mentioned authors, resources are divided into two types, inherited resources and created resources, in addition to supporting factors. Inherited resources can be classified as natural (mountains, lakes, beaches, rivers, climate, etc.) and part of the cultural heritage [cooking, crafts, language, customs, belief systems]. However, the created resources include tourism infrastructure, special events, the variety of activities available, training and shopping. Likewise, supporting factors or resources include general infrastructure, quality of service and accessibility to the destination, hospitality and market ties. These three elements grouped together, as shown in Figure 4 , indicate that destination competitiveness depends on the aggregate value of its base resources and other factors Dwyer \& Kim, [13].

Regarding environment, the factors to consider are the situational conditions of destination management and demand conditions. Dwyer and Kim define situational conditions as those forces coming from 
the external environment that impact destination competitiveness, from the economic, cultural, demographic, environmental, political, legal, governmental, regulations, technological, competitive tendencies and events that impact how companies conduct their processes. Concerning destination management, these are factors that can improve the attractiveness of the destination, from its Basque resources and attractors that can strengthen the quality and effectiveness of the resources, in addition to improving the conditions to adapt to situational or eventual conditions. Finally, the domain of demand conditions includes three main elements of tourism demand: awareness, perception and preferences. Awareness can be generated by various means according to destination marketing activities. In turn, the projected image of the destination can influence perceptions and, therefore, affect visitation. Finally, destination management should be developed around the preferences of the consumer in a way that adapts to their constant changing [1] [14].

Finally, the last key factor is tourism competitiveness. This indicates that destination competitiveness is a basic intermediate objective for the achievement of the fundamental goal of socioeconomic well-being of the residents of the destination. Each objective is associated with a set of indices. They consider both subjective attributes and those that are objectively determined Dwyer \& Kim, [14].

\subsection{Strategic Forecasting as a Driver to Promote Scenarios Aimed at Reaching Competitive Levels}

Forecasting is related to the concepts of strategy and planning, each of which leads to the other. According to this relationship, the terms strategic planning, management and strategic forecasting appear Godet [18]. This is a relatively new topic originating from the contributions made by Ossip Flechtheim in his article "Teaching the Future" in 1945 and the book "History and Futurology" in 1966 in which he attempts to define forecasting as the science that is responsible for conducting different investigations trying to predict the future [41]

After the proposals made by Ossip Flechtheim, during the Second World War, Herman Kahn derived a method to make predictions of the future. The method refers to the scenario planning or scenarios. The central idea is to construct representations of possible futures, as well as the path that could lead to achieving these Godet, [18]. In this sense, scenario planning has been defined in different ways; for Michael Porter, scenario planning is a consistent internal vision of what the future could be Chermack \& Lynham, [10]; however, Schwartz defines scenario planning as a tool to organize perceptions about future alternatives, in addition to the scenarios that have to follow a sequence from the identification of the problem to the identification of key alerting factors [10] [13]

It is important to note the different schools of thought of forecasting although the objective is the same [i.e., anticipating the future] using different methodologies. These schools are the French school, the Anglo-Saxon school and the Latin American school. The latter results from the adaptation and improvement of the postulates of the two pioneering French and Anglo-Saxon schools. Although some authors still do not define it as a "school" per se, it is important to note the work completed by the Economic Commission for Latin America and the Caribbean (ECLAC), the Network of Schools and Scenarios (Red EyE) and authors such as Javier Medina Vázquez and Francisco Mojica.

The French school, also known as the volunteer forecasting school, had its beginnings in France at the end of the Second World War to generate strategies that would allow the reconstruction of the country because of the consequences of the Second World War. Accordingly, various analyses were generated on the future aimed at the possibility of industrial development based on social and economic trends [30].

This school begins with the thoughts of the philosopher Gaston Berger in 1957, and this philosophical training attempted to rethink the future from what the present can provide. In the words of Berger: "the future is the raison d'etre of the present" [19]. For Berger, the forecasting, rather than a method, is an attitude of being; this definition contrasts it with that of retrospective methods, establishing that both are opposed to that prospectively one is projecting into the future and 
contrary to what the retrospective does, which is to look to the past.

Another exponent of the French school was Bertrand de Jouvenel [25], with the publication of the book entitled "The Art of Conjecture" in which he establishes that there are two means of understanding the future: as a single reality and as a multiple reality. The single reality future is understood by those who consider that for each person there is a destination that marks the rhythm and actions of life, this destiny makes the future unique and unmodifiable. However, there is the multiple reality future because the actions of the present can change the future in different forms; these forms are the possible futures that he called the "futuribles".

Within these possible futures, there are some with a greater possibility of happening; these are the probable futures, so called because in them uncertainty and probabilistic studies converge, which give them this characteristic that goes beyond what is possible [25]. However, the main exponent of the French school is Michel Godet, who is influenced by the postulates that Berger and de Jouvenel initially developed in addition to the Anglo-Saxon school and proposes a comprehensive method for building the future. In this order of events, Godet, [17] mentions, "forecasting is a reflection to clarify the present action in the light of possible futures", but it must be taken into account that the future is not the only extension of the past, since it is open to the influence of multiple actors in favour of their own interests or predicted futures.

The Anglo-Saxon school had its beginnings in the early 1950 s by the company RAND after the Second World War. The priority at this time was national security; for this, future studies would be key in this process. RAND, based on the need to understand how to address future military technologies - after leaving the war - and the potential problems, sought to resolve this type of challenge. Then a technique arose that used panels of experts to address different future issues [20]

In this regard, the technique called the "Delphi method", developed by Olaf Helmer, Nicholas Rescher, Norman Dalkey and other thinkers of the company RAND, has been used extensively in different areas; planning, policy analysis and longterm forecasting. Its first application was carried out in 1948 and became popular after the publication of the first scientific article, which was developed in 1963 [22]. This method was based on gathering experts in a common place - conference rooms, panels - and learning their opinions on different topics to reach a consensus on what future technologies would mainly be, i.e., this method focused on technological forecasting [20]. The main objective of the method was to obtain the most reliable consensus of the opinions of a group of experts. Because the number of respondents is generally small, the Delphi method does not produce statistically significant data or results; even so, the conclusions that can be drawn from the application of the method are valid [20].

In Latin America, from the 1990s, attempts were made to construct theories and practical manuals on future studies. ECLAC has played an important role in the development of forecasting studies in the region since it has supported and led these studies in various countries. Various methods have been proposed in this school. These have been adaptations to what was initially established in the French and Anglo-Saxon schools. In summary, the proposed methods have been of relevant authors in forecasting studies of Latin America, which are Francisco Mojica, Javier Medina Vásquez and Raúl Balbi. Francisco Mojica makes important contributions to the literature on forecasting in Latin America, analysing the different methodologies presented in the French and Anglo-Saxon schools. He considers that there has been a strong influence of the United States and Europe in Latin America and that this has allowed for the blending of different methodologies such as the Delphi method and the scenario method as an alternative for conducting future studies in Latin America [33]. However, Mojica proposes an update of the method of scenarios proposed by Godet in which he takes into account, in addition to what was presented by the French school, technological surveillance, the state of the art and the role of actors. This is titled "Model of Greater Complexity of Strategic Forecasting" [33].

The contributions of Javier Medina Vásquez to future studies have been significant. His article entitled "Scenarios as Seen from a Human and Social Perspective" examines how scenarios can be more than tools for future studies; he argues that 
these should be seen from epistemological, methodological and ethical criteria due to the role of culture, among other factors, which gives it a social and human perspective when constructing scenarios [29]. Similarly, Medina Vásquez creates a reference document for the application of forecasting in Latin America entitled "Manual of Strategic Forecasting and Decisions: Theoretical Bases and Instruments for Latin America and the Caribbean"; in this, he proposes a theoretical-conceptual model with the goal of promoting the growth, competitiveness and equity of society as a whole [31]. Eduardo Balbi poses the MEYEP method, which arises from the need to make an explicit procedure that would allow those interested in forecasting to carry out a study that would range from the understanding of the studied problem through the characterization of the system, the analysis of the factors that influence it and the future possibilities that lead mainly to the development of strategies and actions to be implemented to achieve the desired future so that this is not the most likely to occur [4].

\section{Methodology}

The results presented are exploratory, framed within the qualitative paradigm, understanding the competitive dynamics of the territory and establish future development scenarios. In this methodology, we identifying actors and key variables for the development of the island region of Isla Grande, Archipelago of Islas del Rosario and the identification of scenarios with greater probabilities of occurrence according to the politicaladministrative actions exercised in this area, based on the forecasting and scenario planning method.

The study was developed in three phases. In the first, a regional diagnosis was performed by applying a competency tree to identify the internal and external variables that affect the region of Isla Grande; Using a PEST analysis, the dimension of external variables, were determined according to Political, Economic, Social, Technological, Environmental and Legal [9] [28]. The dimension of internal variables was develop through competition tree in order to have an image of the territory and identifying distinctive competencies and their dynamics [18]
In this sense, analysis of the environment was performed with visits to the region in which the current situation of the island was verified. During these visits, a tour around the entire region was carried out, and pockets of development and poverty were identified. Once the environment was analysed, the information collected was validated, holding community workshops for feedback on the information gathered initially to, thus, have a better picture of the region.

Finally, the key variables that dynamize the system were determined through structural analysis performed in MICMAC. The second phase includes stakeholder analysis. In this phase, it was important to identify the actors and their relevance. A mapping of actors was performed based on secondary information and information provided by the community to determine their objectives and influence with respect to other actors in the system. In the third phase, the cross probabilistic impacts that determine the simple and conditioned probabilities of the scenarios are identified.

\section{Results}

The diagnosis of the region's surroundings made with a competency tree and the PESTAL analysis determined that the internal factors that affect the island revolve around four domains: economic, sociodemographic, environmental and legal. Likewise, the competency tree identifies the importance of the sociodemographic domain, which presents ten [10] internal factors that affect the island. The second domain that is representative of Isla Grande is the economic domain. This contains six [6] internal factors that show the internal capacities of the island in the generation of income.

Based on the results of the PESTAL analysis, as in the competency tree, the sociodemographic domain is the most representative in terms of external factors that may affect the Isla Grande. Within this domain, most of the factors analysed turned out to be a possible threat to the region, i.e., factors such as quality and coverage in education, public services, health services and the poverty and misery index. Only one analysed factor can be an opportunity, and it is literacy. 
Another relevant domain from the exogenous point of view is the environment, but unlike the sociodemographic domain, it presents a lower number of external factors such as sea level that is conceived as a threat and the access route to Barú, considering the latter is both an opportunity and a threat. This is explained by the fact that with the construction of the road to Barú, there will be the possibility of increasing the number of tourists due to greater accessibility to the island from Barú, which will generate a multiplying effect by impacting all of the economic factors on the island. However, Barú can also be considered a threat because, by having greater accessibility to the island, not only tourists but also natives of other neighbouring islands will be able to access it. If these people do not have the same ethical or moral values that characterize the inhabitants of the island, this could translate into an increase in citizen insecurity and increased environmental pollution among other factors.

The competency tree and PESTAL tools identified thirty-seven [37] variables relevant to the region. These variables were analysed using a matrix of direct impacts representing the relationship between two variables [2][28][10]

This relationship is determined by the influence of one variable on another. The variables are classified according to their importance, as follows:

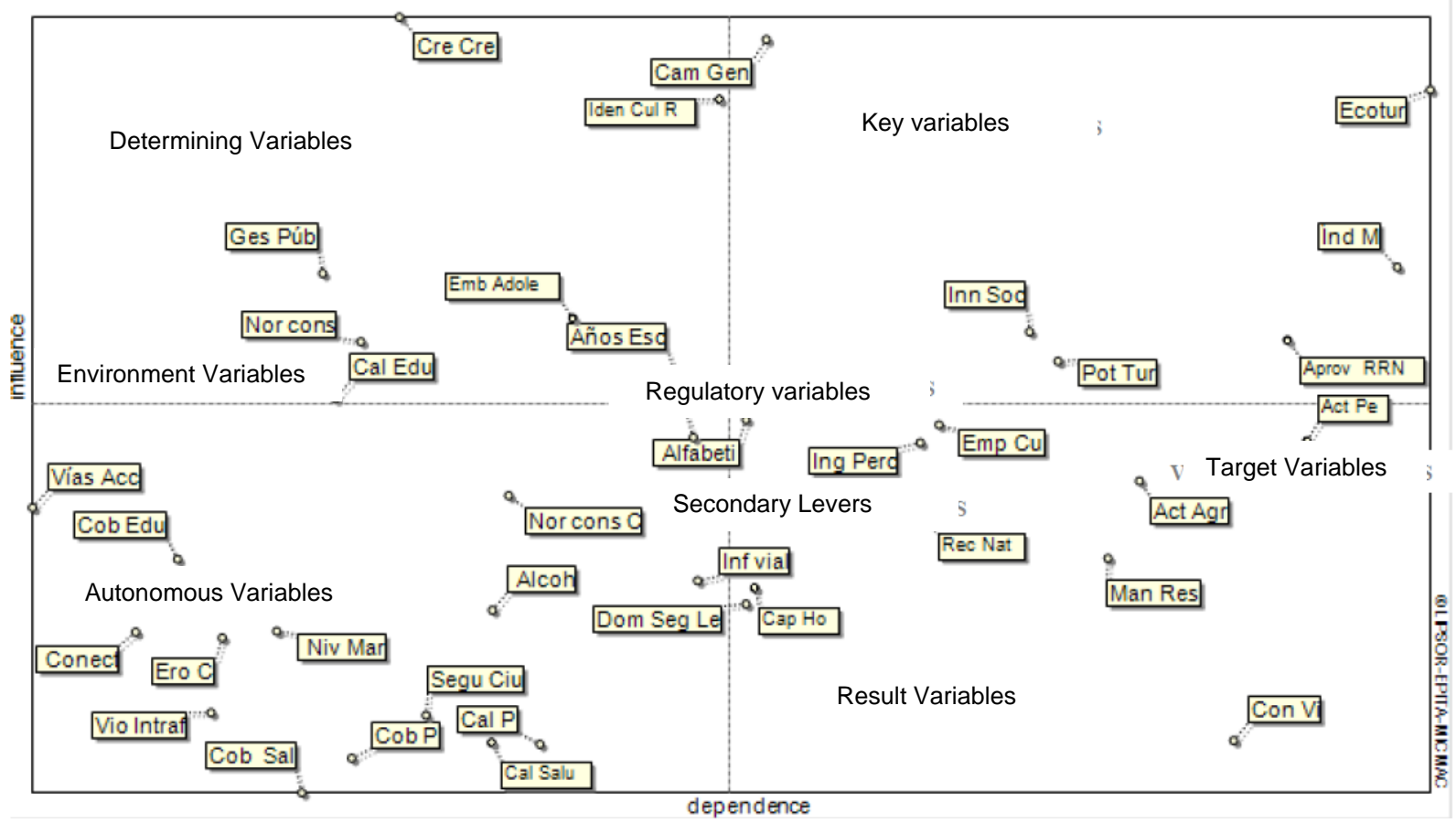

Fig. 2. Indirect influence matrix

Source: Prepared by the authors.

\subsection{Key Variables}

The key variables are those that have a high influence and high dependence and are found in quadrant 1 of the Cartesian plane. These are the variables that invigorate the entire system because acting on one of them generates an effect on the rest [2] [16]

For Isla Grande, the key variables were as follows:

- Ecotourism

- Poverty and misery index
- Exploitation of natural resources

- Tourism potential

- Generational exchange

These variables are the priority factors for change in Isla Grande. With this, the analysis of actors, scenarios and strategies will be in step with them.

\subsection{Determining Variables}

These variables can be found in the upper left-hand side of the plane of influence, and depending on their evolution, they can be the brakes or drivers of 
the system; that is, they can be propulsive or inhibitory to the system Garza \& Cortez, [2011]. The determining variables that resulted from the MICMAC analysis are as follows:

- Beliefs

- Regional cultural identity

- Public management

\subsection{Environmental Variables}

These variables have little dependence and are considered "accessories" to the plane of influence Garza \& Cortez, [2011]. They are as follows:

- Norms of conservation

- Quality of education

- Teen pregnancy

\subsection{Regulatory Variables}

These variables located in the central zone become catalysts to achieve the objectives of the key variables. They determine the proper functioning of the system Garza \& Cortez, [2011]. These are as follows:

- Years of schooling

- Literacy

\subsection{Secondary Triggers}

They are conceived as complementary variables to the regulatory variables; that is, if they are acted upon, they, in turn, will have an effect on the regulatory variables Arcade et al., [2004]. For Isla Grande, these variables are as follows:

- Regional conservation norms such as collective title to lands

- Hotel capacity

- Road infrastructure

- Second language proficiency

- Alcoholism

\subsection{Objective Variables}

The objective variables are those that are very dependent and moderately motorized and have an objective character due to their nature because they can be influenced so that their evolution is as desired Garza \& Cortez, [2011]. For Isla Grande, these variables are as follows:

- Fishing activity

- Agricultural activity

- Management of solid waste

\subsection{Outcome Variables}

The outcome variables are characterized by having low motor skills and high dependence. They are presented as descriptive indices of the evolution of the system. To influence these variables, it is not possible to do so directly, but indirectly, that is, those that depend on the system [Garza \& Cortez, 2011]. In Isla Grande, the outcome variable is as follows:

- Housing conditions

\subsection{Autonomous Variables}

These variables have little influence and dependence and are related to past trends or inertia of the system, i.e., they are disconnected from it Garza \& Cortez, [2011]. For Isla Grande, the autonomous variables are follows:

- Access routes [via Barú]

- Education coverage

- Coastal erosion

- Connectivity

- Sea level

- Coverage of public services

- Family violence

- Quality of health services

- Citizen safety

- Quality of public services

The different key actors identified that give dynamism to the system are of vital importance for the design of strategies and public policies because it is necessary to prioritize them for taking actions according to their influences and dependencies with respect to other actors. Figure 3 shows the results of the MACTOR analysis, which represents the dependencies along the $\mathrm{X}$ axis while the $\mathrm{Y}$ axis represents the influence.

\subsection{Key Actors}

- Ancestral community

- State

- Police inspector

- Board of directors of the community council

- Businessman leader

- Evangelical pastors

- Rector of the educational institution Islas del Rosario

- Representative of the cultural house

- Legal representative of the community council 


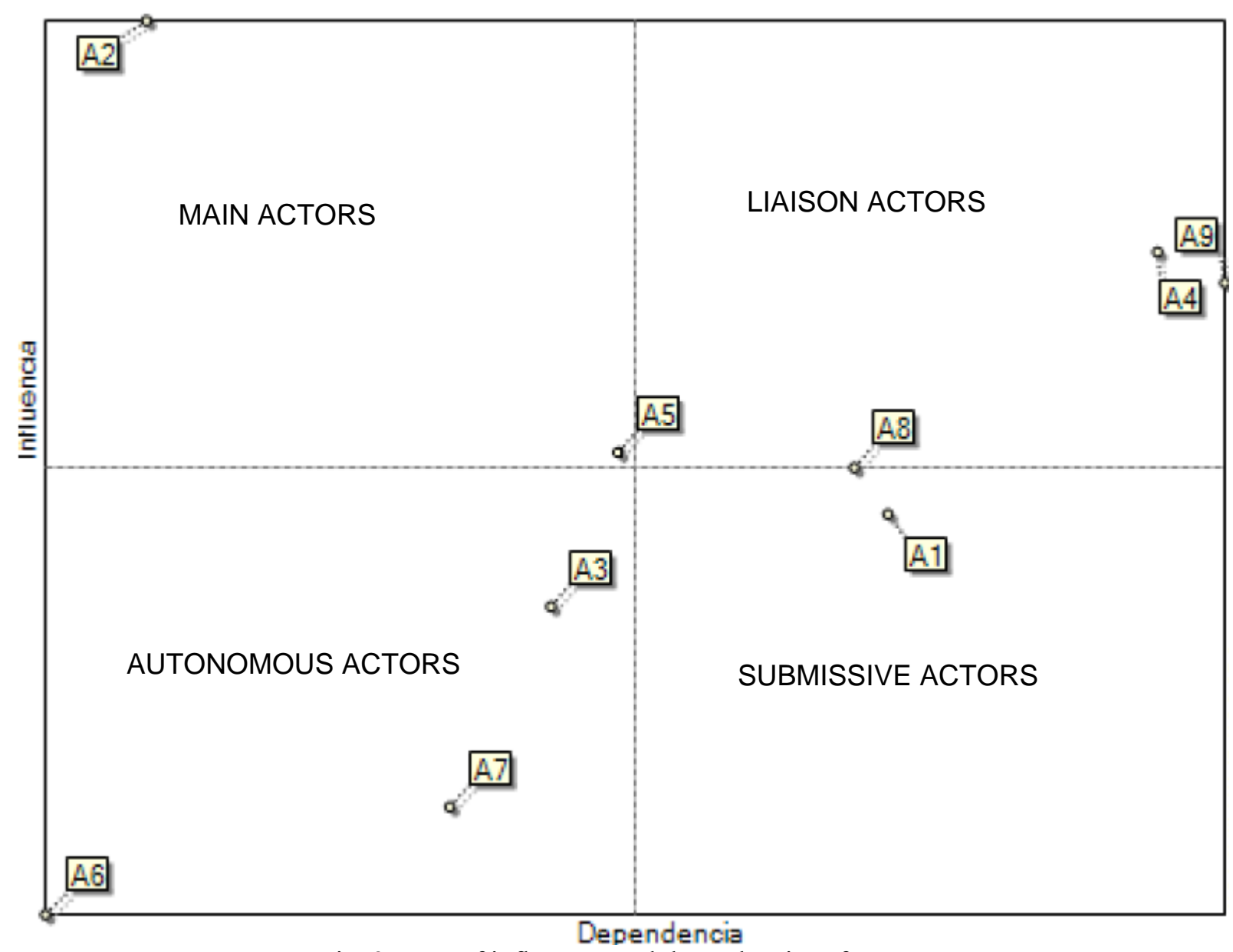

Fig. 3. Map of influences and dependencies of actors Source: Prepared by the authors.

\subsection{Dominant Actors}

The dominant actors are those who have a high influence and a reduced dependence with which they can act on the system without being limited or disturbed by other actors. In the case of Isla Grande, they are as follows:

A2 $=$ State

A5 $=$ Business leaders

\subsection{Liaison Actors}

In the case of liaison actors, they have a high influence but also a high dependence, which means that through these strategies, the strategies can be channelled as they "connect" to the system. In Isla Grande, these actors are as follows:

A9 $=$ Legal representative of the council

A4 $=$ Board of directors of the community council

A $8=$ Representative of the cultural house

\subsection{Autonomous Actors}

Autonomous actors have little influence and dependence within the system, meaning that their actions do not affect other actors nor are they influenced by the decisions of others. In Isla Grande, these actors are as follows:

A $3=$ Police inspector

A7 $=$ Rector of the educational institution Islas del Rosario

A6 = Evangelical pastors

\subsection{Submissive Actors}

Finally, submissive actors are characterized by having little influence and much dependence on which their categorization depends on the actions of other actors to contribute to the system. For Isla Grande, the submissive actor is as follows:

A1 $=$ Ancestral community 


\subsection{Strength of Actor Relationships}

It is necessary to complement the plane of influence and dependence of actors through the histogram of strength relationships of actors [see Figure 4], which shows the weight that the actors have in the system, organized by the number of actors in each.

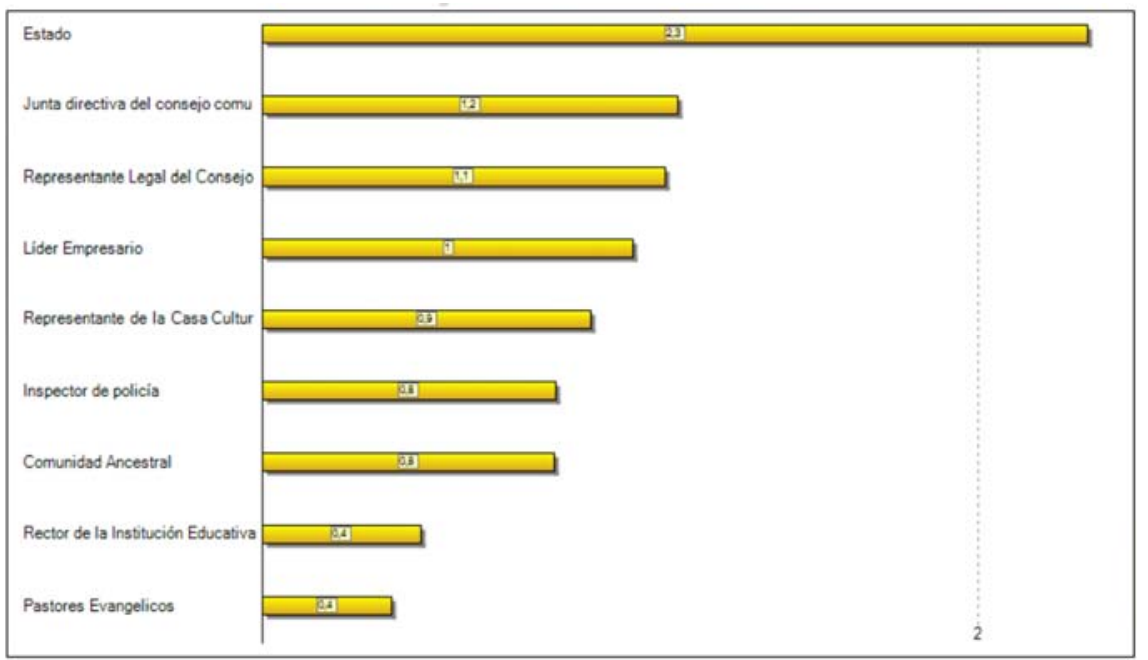

Fig. 4. Histogram of relationship strength between actors Source: Prepared by the authors.

It can be inferred from Figure 4 that the most dominant and influential actor in the entire system is the State. Due to their nature and influence in the community, so are the actors of the board of directors of the community council and the legal representative of the council.

Likewise, the weakest links within the system are the evangelical pastors and the rector of the educational institution. Finally, the actors business leader, representative of the cultural house, police inspector and the ancestral community are of intermediate relevance.

\subsection{Scenario Design - Peter Schwartz Axes}

The construction of the Peter Schwartz scenarios is performed with scenario simulations defining possible situations that may occur in the region under study in the future. Constructing the axes requires the definition of a competitive environment in the medium and long term. With this, axes called "Schwartz axes" are proposed. In this case, the result of the analysis of the key variables identifying the categories or families that can be grouped are placed on the X axis; thus, for the case of Isla Grande, two families of variables are obtained: environmental and socioeconomic [Ringland \& Schwartz, 1998]. Once this is completed, outlining of the probable scenarios is performed according to the quadrants of the Cartesian plane, as observed below:

Table 1. Strategic variables

\begin{tabular}{|c|c|}
\hline No. & Strategic variables \\
\hline 1 & Ecotourism \\
\hline 2 & Poverty and misery index \\
\hline 3 & Exploitation of natural resources \\
\hline 4 & Social innovation \\
\hline 5 & Tourism potential \\
\hline 6 & Generational change \\
\hline
\end{tabular}

Source: Prepared by the authors.

Table 2. Classification of strategic variables

\begin{tabular}{|c|c|}
\hline Family of variables & Variables of the family \\
\hline \multirow{4}{*}{ Environmental } & Ecotourism \\
\cline { 2 - 2 } & $\begin{array}{c}\text { Tourism potential } \\
\text { Exploitation of natural } \\
\text { resources }\end{array}$ \\
\cline { 2 - 2 } Economic & \begin{tabular}{c} 
Social innovation \\
\cline { 2 - 2 }
\end{tabular} \\
\cline { 2 - 2 } & Poverty and misery index \\
\hline Sociodemographic & Generational change \\
\hline
\end{tabular}


Table 3. Categorization of the family of variables

\begin{tabular}{|c|c|}
\hline Category & Family \\
\hline Environmental & Ecotourism \\
\hline \multirow{2}{*}{ Economic } & \multicolumn{2}{|c|}{ Economic } \\
\cline { 2 - 2 } & \multicolumn{2}{|c|}{ Sociodemographic } \\
\hline Source: Prepared & by the authors.
\end{tabular}

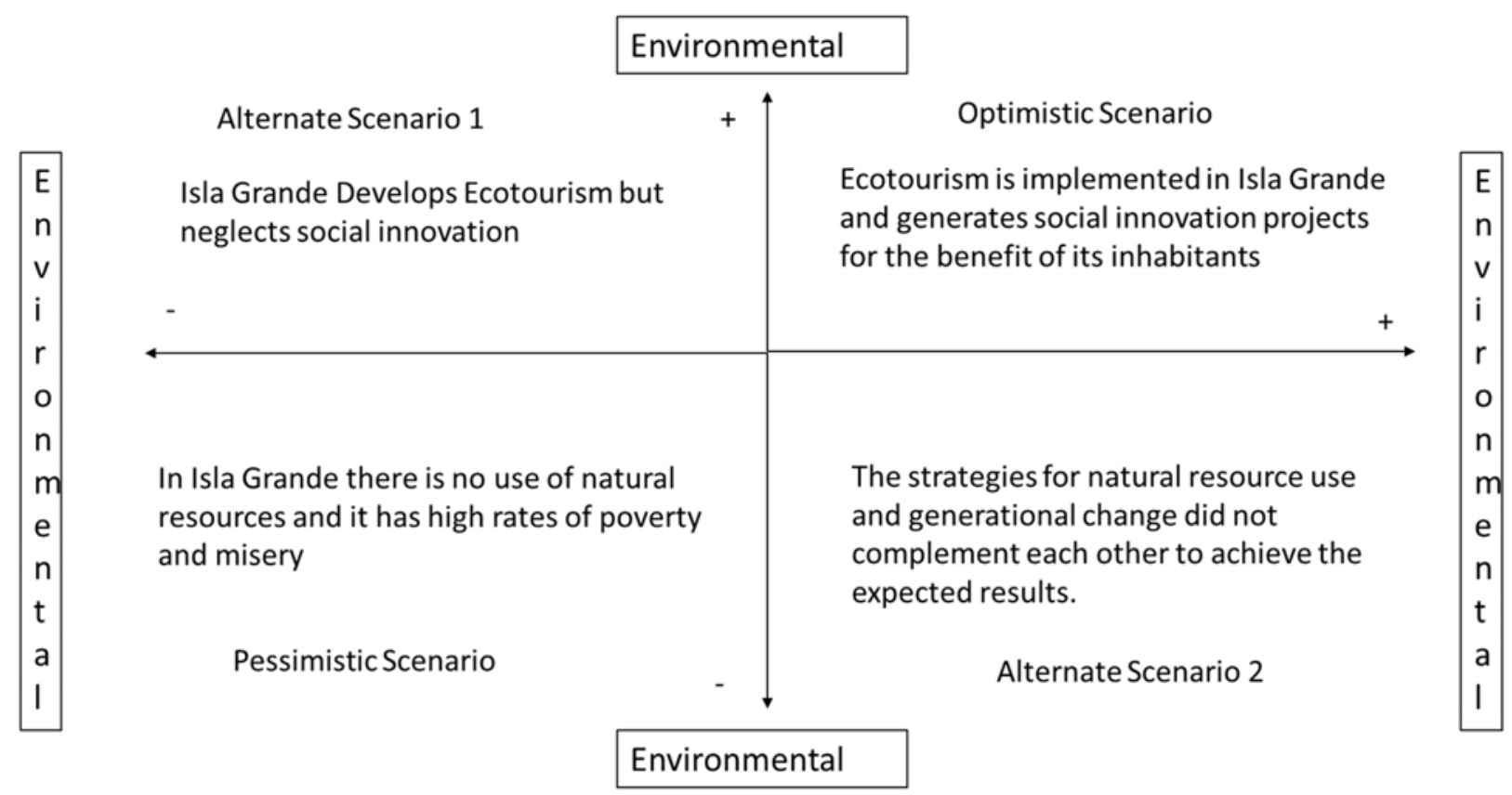

Fig. 5. Scenarios - Peter Schwartz

\section{Scenario 1. Optimist}

Isla Grande in 2030 implements ecotourism [+] as an economic activity, demonstrating the natural attractiveness of the region, which produces an increase in tourism potential according to the exploitation of natural resources. The ancestral community exercises leadership in conjunction with the representative of the Cultural House and the Legal Representative of the Community Council for the implementation of social innovation projects [+] that allow the island to aim to be considered ecosustainable. The State supports these initiatives by providing spaces for the construction of the dream island through the mayor's office and government.

\section{Scenario 2. Alternative 1}

Isla Grande develops ecotourism [+]; however, it neglects social innovation [-], which increases the visibility of tourist attractions based on ecological tourism. Business leaders are the ones who lead the destination promotion initiatives, as well as the legal representative of the council and the board of directors of the community council.

\section{Scenario 3. Alternative 2}

The strategies of exploitation of natural resources [-] and generational change are not complemented to achieve the expected results. Through the legal representative of the community council, alternatives are sought in the face of various institutions [public, private and NGOs] for the financing of projects that allow the exploitation of the island's natural resources for meeting the unsatisfied basic needs and decreasing the misery and poverty index $[+]$.

\section{Scenario 4. Pessimistic}

Isla Grande does not exploit its natural resources [-] and has high rates of poverty and misery [-]; despite 
the attempts of the board of directors of the community council to promote and find projects that can meet the unsatisfied basic needs of the islanders together with the legal representative of the community council before public institutions, the proposal is not achieved, putting at risk the quality of life of the inhabitants of the island, and as a result, the demotivation that ultimately leads to misuse of the natural resources. Distancing the possibility that Isla Grande is a highly competitive region through its ecotourism that characterizes and differentiates it from other islands in the region for its comparative advantage.

Ultimately, the scenario for which the region should be wagered [best-bet scenario] is the last one. For Isla Grande to become an "optimist" requires the combination of environmental and socioeconomic domains and involves its stakeholders in the competitiveness that the island so desires and needs. This scenario would not occur if actions are not taken from now on with changes that lead to it. Should the region not move to this scenario, it will go in the pessimist direction or to any of the alternative scenarios posed above. However, if the appropriate strategies and appropriate actions at the environmental and socioeconomic level are adequate, Isla Grande can achieve the optimistic scenario by 2030 .

The best-bet scenario is related to what was proposed by Dwyer and Kim, [2003] because the prioritization of both inherited and created resources are determinant for being competitive in the destination. From the natural strengths of Isla Grande, it is important to promote destination management that prioritizes and directs the activities and improvements in these resources without neglecting their sustainability in the medium and long term. In addition, the improvement of this competitiveness is a tool for a final objective and is the social and economic well-being of the population of Isla Grande. With this, we say that the future will not happen randomly but that the island should start building it now.

\section{Conclusions}

The key variables represent a high influence and dependence, being a key element to boost the system because acting on them affects the other variables. In the community of Isla Grande, the key variables identified were ecotourism, index of poverty and misery, exploitation of natural resources, social innovation, tourism potential and generational change. It is necessary to indicate that the aforementioned variables are the pillars for the generational change in Isla Grande. With this, the analysis of actors, scenarios and strategies should be directed towards them.

However, the dominant actors who have a high influence and a reduced dependence that can act on the community without being limited or disturbed by other actors are the State and business leaders.

For the scenarios planned for Isla Grande in 2030, the results obtained are synthesized in which four [4] scenarios were proposed. The optimistic scenario, or one to which the region must be led to achieve the desired competitiveness, is the following: "Isla Grande in 2030 implements ecotourism $[+]$ as an economic activity, demonstrating the natural attractions of the region, which produces an increase in tourism potential in line with the exploitation of natural resources. The ancestral community exercises leadership in conjunction with the representative of the cultural house and the legal representative of the community council for the implementation of social innovation projects $[+]$ that allow the island to aim to be considered ecosustainable. The State supports these initiatives by providing spaces for the construction of the dream island through the mayor's office and government."

Ultimately, the scenario for which the region should be wagered [best-bet scenario] is the last one. Isla Grande becoming an "optimist" is due to the combination of environmental and socioeconomic domains and involves its stakeholders in the competitiveness that the island so desires and needs. This scenario would not occur if actions are not taken from now on with changes that lead to the desired scenario.

According to Dwyer and Kim (2003), the strategic variables for the Isla Grande have been related to situational conditions. We found that key variables as ecoturism, poverty and misery, generational change, its need to be changed in order to achieve 
the optimistic scenario. However, the articulation of the state, the companies and the society that allow the dynamization of the established strategic variables is needed.

In conclusion, the future will not occur randomly, but rather, the island should start building its future now, aimed at the strategic proposals that tend to reach the best-bet scenario for Isla Grande by 2030 . Some of the immediate actions suggested that reach the desired scenario are promotion as an ecotourist destination and awareness campaigns about the importance and possibilities offered by the island's natural resources, among others.

Finally, we find a cultural distinction between the inhabitants of Isla Grande and the rest of the inhabitants of the city due to their sense of belonging to the territory. Research is needed to understand this cultural distinction

\section{Acknowledgements:}

This research included funding from the Universidad Tecnológica de Bolívar. We recognize the contributions of the various stakeholders that actively participated in the entire development of the research in which the community is highlighted through its board of local action, affiliated educators in the teaching profession, members of the national police, merchants, native founders and leaders of the evangelical and catholic communities, as well as members of the mayoralty of the District of Cartagena de Indias; without the actors described above, it would not have been possible to obtain the results presented.

In addition, we appreciate the significant revisions and contributions of the following teachers: Jhon Vidal, Jorge Martinez and Dario Sierra.

\section{References:}

[1] Ambastha, A., \& Momaya, K. [2003]. Competitiveness of Firms: Review of Theory, Frameworks and Models. Singapore Management Review, 26[1].

[2] Arcade, J., Godet, M., Meunier, F., \& Roubelat, F. (2004). Análisis estructural con el método Micmac y estrategia de los actores con el método Mactor. In Futures Research Methodology, Version 1.0(pp. 165-233)

[3] Avendaño Avendaño, M., Mondragon, S., \& Fuertes Diaz, M. [2018]. Retos Y Desafíos De
La Competividad Y Sostenibilidad De Los Territorios Al Año 2030. Documentos de Trabajo ECACEN, 1. https://doi.org/https://doi.org/10.22490/ECACE N.2589

[4] Balbi, E. [2010]. Manual Básico del Método Oficial de Prospectiva de la Red EyE [Escenarios y Estrategia] en América Latina.

[5] Barney, J., Wright, M., \& Ketchen, D. J. [2001]. The resource-based view of the firm: Ten years after 1991. Journal of Management, 27[6], 625-641. https://doi.org/10.1016/S01492063[01]00114-3

[6] Bolfa Traian Eugen, [2019]. Studies Regarding Tourism Development Perspectives in the Existing Economical and Environmental Context. WSEAS Transactions on Environment and Development, pp. 197-203, Volume 15.

[7] Budd, L., \& Hirmis, A. K. [2004]. Conceptual framework for regional competitiveness. Regional Competitiveness, [September 2012], 25-38. https://doi.org/10.4324/9780203607046

[8] Castrillón, I. D., Canto, A. G., Cantorna, A. S., \& Cerradelo, L. B. [2011]. Analisis de los principales modelos explicativos de la competitividad de los destinos turisticos en el marco de la sostenibilidad. Aqruivos, 5[2].

[9] Chapman, A. (2004). Análisis DOFA y Análisis PEST. Retrieved from http://clasev.net/v2/pluginfile.php/27785/mod_r esource/content/2/AnalisisFODAyPEST.pd

[10] Chermack, T. J., \& Lynham, S. A. [2002]. Definitions and Outcome Variables of Scenario Planning. Human Resource Development Review, 1[3], 366-383. https://doi.org/10.1177/1534484302013006

[11] Consejo Privado de Competitividad y Universidad del Rosario. [2016]. Índice Departamental de Competitividad.

[12] D' Hauteserre, A.-M. [2000]. Lessons in managed destination competitiveness: the case of Foxwoods Casino Resort. Tourism Management, 21[1], 23-32. https://doi.org/10.1016/s0261-5177[99]00097-7

[13] Del Rio, J. L., \& Julio, J. del C. (2014). Cruzando El Puente: De La Selva De La Planeación Estrategica a La Construcción Prospectiva De Escenarios. Global Conference on Business and Finance Proceedings, 9(2), 2016-2024 
[14] Dwyer, L., \& Kim, C. [2003]. Destination competitiveness: Determinants and indicators. Current Issues in Tourism, 6[5], 369-414. https://doi.org/10.1080/13683500308667962

[15] Gândara, J. M. G., Chim-Miki, A. F., Domareski-Ruiz, T. C., \& Biz, A. A. [2013]. La Competividad Turística De Foz Do Iguaçu Según Los Determinates Del Integrative Model De Dwyer \& Kim: Analizando La Estrategia De Construción Del Futuro. Cuadernos De Turismo, 31[1], 105-128.

[16] Garza, J., \& Cortez, D. (2011). El uso del metodo MICMAC y MACTOR analisis prospectivo en un area operativa para la busqueda de la excelencia operativa a traves del Lean Manufacturing. Innovaciones de Negocios, 8(2), 335-356.

[17] Godet, M. [1986]. Introduction to la prospective. Futures, 18[2], 134-157. https://doi.org/10.1016/0016-3287[86]90094-7

[18] Godet, M. [2000]. El Análisis Estructural. Cuadernos de LIP, Número 5: La Caja de Herramientas de La Prospectiva Estratégica, 68-73.

[19] Godet, M., Durance, P., Por, T., Cortina, K. G., Dirigida Por, C., Giget, M., ... Perseil, S. [2009]. Cuaderno del Lipsor La prospectiva estratégica para las empresas y los territorios El Cercle des Entrepreneurs du Futur Cuadernos del Lipsor.

[20] Gordon, T. J. [1994]. The Dolphi Method. AC/UNU Millennium Project, 16[5], 411-430. https://doi.org/10.1007/BF02197902

[21] Grant, R. M. [1991]. The resource-based theory of competitive advantage: implications for strategyformulation. California Management Review, 33[3], 114-135.

[22] Gupta, U. G., \& Clarke, R. E. [1996]. Theory and applications of the Delphi technique: a bibliography [1975-1994]. Technological Forecasting and Social Change, 53[2], 185$211 . \quad$ https://doi.org/10.1016/S0040$1625[96] 00094-7$

[23] Heath, E. [2003]. Towards a model to enhance destination competitiveness: a Southern African perspective. Journal of Hospitality and Tourism Management, 10[2], 124-141.

[24] Hernández, H. G., Cardona, D. A., \& Del Rio, J. L. [2017]. Direccionamiento estratégico: Proyección de la innovación tecnológica y gestión administrativa en las pequeñas empresas. Informacion Tecnologica, 28[5], 1522. 07642017000500003

[25] Jouvenel, B. de. [1967]. The Art of Conjecture. London.

[26] Kozak, M., \& Rimmington, M. [1999]. Measuring tourist destination competitiveness: conceptual considerations and empirical findings. International Journal of Hospitality Management, 18[3], 273-283. https://doi.org/10.1016/s0278-4319[99]00034-1

[27] Krugman, P. [1994]. Competitiveness: A Dangerous Obsession. Foreign Affairs, 73[2], 28. https://doi.org/10.2307/20045917

[28] Martínez, D., \& Milla, A. (2012). Análisis del entorno. In Elaboración del plan estrategico y su implantación a traves del cuadro de mando integral(pp. 33-80). Madrid, España: Diaz De Los Santos S.A.

[29] Masini, E. B., \& Vasquez, J. [2000]. Scenarios as Seen from a Human and Social Perspective Scenarios: Something More Than a Tool? Technological Forecasting and Social Change, 65, 49-66.

[30] Medina, A. [2003]. Diseño, desarrollo e innovación del currículum. Madrid, España: Universitas.

[31] Medina, J., \& Ortegón, E. [2006]. Manual de prospectiva y decisión estratégica: bases teóricas e instrumentos para América Latina y el Caribe. Insituto Latinoamericano y Del Caribe de Planificación Económica y Social [ILPES], 438.

[32] Mitma, J., Pinzás, A., \& Contreras, C. (2009). Prospectiva estratégica al sector textil del distrito de San Juan de Lurigancho. Producción Y Gestión, 12(2), 40-49.

[33] Mojica, F. J. [2010]. Introduccion a la prospectiva Estrategica para la competitividad empresarial [Universida].

[34] Morales, M., \& Pech, J. [2000]. Competitividad y Estrategia: el Enfoque, de las Competencias Esenciales y el Enfoque Basado en los Recursos. Contaduría y Administración, 197[1], 46-63.

[35] Nurhayati, Isah Aisyah \& Asep K. Supriatna [2019]. The Relevance of Socioeconomic Dimensions in Management and Governance of Sea Ranching. WSEAS Transactions on Environment and Development, pp. 78-88, Volume 15. 
[36] Peteraf, M. [1993]. The Cornerstones of Competitive Advantage: a Resource Based View. Strategic Management Journal, 14[April 1992], 179-191. https://doi.org/10.1017/CBO9781107415324.00 4

[37] Porter, M. [2000]. Location, Competition, and Economic Development: Local Clusters in a Global. Harvard Business School, 14[1], 15-34. https://doi.org/10.1177/089124240001400105

[38] Prahalad, C. K., \& Hamel, G. [1990]. The Core Competence of the Corporation. Harvard Business Review, 68[3], 79-91.

[39] Reinert, E. S. [1994]. Catching up fromWay behind: a Third World View Pers-pective on First World History. He Dynamics of TeChnology: Trade and Growth.

[40] Ritchie, J. R. B., \& Crouch, G. I. [2000]. Lessons in managed destination competitiveness: the case of Foxwoods Casino Resort. Tourism Management, 21[1], 23-32. https://doi.org/10.1016/s0261-5177[99]00097-7

[41] Vergara Schmalbach, J. C., Maza Ávila, F., \& Fontalvo Herrera, T. J. [2010]. Potencialidad de asociatividad de restaurantes del centro histórico de la ciudad de Cartagena de indiasColombia. Revista Facultad de Ciencias Económicas, 18[2], 137-146. https://doi.org/10.18359/rfce. 2276

[42] WEF. [2016]. World Economic Forum Annual Meeting.

[43] World Tourism Organization. [2017]. UNWTO Annual Report 2017. 